\title{
Restoration Volunteering as a Social Phenomenon of Modern History
}

\author{
Natalia I. Gorlova ${ }^{1}$ \\ Zulfiya A. Troska ${ }^{1}$ \\ Larisa I. Starovojtova ${ }^{2}$ \\ Tatiana E. Demidova ${ }^{2}$ \\ Anna G. Akhtyan ${ }^{2}$ \\ Aleksandra S. Shcheglova ${ }^{2}$ \\ ${ }^{1}$ Plekhanov Russian University of Economics, Moscow, Russia \\ ${ }^{2}$ Russian State Social University, Moscow, Russia
}

Doi: 10.2478/ajis-2019-0026

\section{Abstract}

Relevance of the problem under study is explained by the beginning of a new stage in the development of Russian volunteer movement in the field of preservation of cultural monuments, which coincided with the rise of research interest in volunteering in general. The objective of this paper consists in comprehensive analysis of the modern history of restoration voluntary movement in Russia, examination of evolvement of public voluntary practices in the field of protection of the architectural heritage of the country in the context of general cultural, socio-economic, political processes that have taken place in Russia over the past decades, which have determined the specific organizational forms, content and activities of voluntary activists. The leading approach to the study of this problem is the historical method, as well as methodological principles of historicism, scientificity, objectivity, as well as sociality, integrity and fundamentality, involving the study of the historical process of volunteering in the totality of facts and sources in their logical and chronological sequence. The paper describes the main forms of volunteer practices for monument preservation, gives an overview of volunteer initiatives, as well as the efforts of charitable foundations and public organizations aimed at rescuing the cultural heritage of the country, identifies the development trajectories of restoration volunteering, and also specifies the key trends, based on which the tendency to professionalization and gradual expansion of the scope of voluntary work has been revealed. Materials of the paper can be useful not only for scientists, engaged in research of problems of social history of our country, but also for specialists from social sphere, organizers of work with youth, and also students of socio-humanitarian and pedagogical profiles.

Keywords: volunteers, volunteer restoration movement, restoration teams, history, cultural monument

\section{Introduction}

Over the recent years, volunteering in the sphere of preservation and restoration of historical and cultural monuments has again become high on the agenda in Russia, and it is not accidental. According to the State Report on the Culture in the Russian Federation in 2017, there are 143,876 cultural heritage sites in the country, out of which about $30 \%$ of the monuments are unowned. According to experts, from $50 \%$ to $85 \%$ of the sites are in unsatisfactory condition While 4,759 licensed organizations and individual entrepreneurs had the right to perform activities to preserve 
cultural and historical monuments in 2017, with the involvement of 5,607 certified restoration specialists, it was insufficient compared to the number of the sites in need of conservation and restoration (State Report, 2017).

With due regard for the above statistical data, low level of state financing, duration and labor intensity of restoration works, it can be concluded that without additional measures for preservation and restoration of historical and cultural monuments a large portion of cultural heritage sites in Russia will be under a threat of extinction in the coming decades.

The development and popularization of restoration volunteering can become such a social and economic measure, which will allow multiplying the number of workers involved in safeguarding and restoration works. At the same time, wide involvement of volunteers in the preservation of cultural heritage sites will help not only to accelerate the process of restoration of historical and cultural monuments, but also to accomplish certain goals of patriotic education of citizens. By participating in the preservation of cultural heritage, volunteers will improve their knowledge of the history of their homeland, learn how to treat monuments more carefully and share their settled worldviews with the peers.

\section{Literature Review}

At the moment, in the national historiography this sector of volunteering in the field of cultural heritage preservation is represented by a small number of publications. In domestic historiography, this problem remains understudied.

Historical aspects of the involvement of volunteers and building the restoration volunteer movement, especially in the 1960-1980s, are only fragmentarily described in a few papers by V.A. Livtsov $(2011,2015,2017)$ as part of the coverage of the historical development stages of the All-Russian Society for the Protection of Historical and Cultural Monuments.

Among the works summarizing the experience of public forms of monument and protection activities by voluntary activists is a monograph by A.M. Kulemzin (2001), papers by N.I. Gorlova (2017a, 2017b). The regional component of the restoration voluntary movement is very implicitly touched upon in the papers by I.V. Golotin (2011), L.P. Ermolenko (2014), A.A. Efremova, O.M. Sokolova, Yu.A. Varfolomeev (2003). The works of N.V. Pereslegin (2015) assess the contribution by the voluntary public in the field of architectural monuments protection.

The works of foreign authors are interesting in their approaches to studying the history of the volunteer movement. They are a product of the in-depth analysis of the vast layers of history and directions of modern volunteer practices (Ascoli \& Cnaan, 1997; Stjernø, 2009; Beito, 2003; Donnelly, 2006). Special interest is aroused by the research of a group of authors, who present their analysis of volunteers' participation in various cultural-historical projects and programs aimed at the preservation of architectural heritage sites of a particular country (Lin, 2010; Murzyn-Kupisz \& Działek, 2013). In broad terms, the works of foreign researchers are highly appealing due to independence of judgments, validity of conclusions, reasonableness and objectivity in statements and assessments.

\section{Research Methodological Framework}

The objective of our research is to analyze the history of restoration volunteering in the context of modern history. The authors have identified the following tasks for this research: examine how volunteer practices have been built up, explore organizational forms and activities of volunteers in the field of protection of the country's architectural heritage. Both theoretical and applied methods were used for the research. This is the principal position of the authors to present the proven and verified experience in finding a balance between the theory and practice at all levels of research of the Russian volunteer movement in the field of preservation of cultural monuments of the country. Comprehension of the problems raised by the research is based on the methodological principles of historicism, scientificity, objectivity, as well as sociality, integrity and fundamentality, involving the study of the historical process of volunteering in the totality of facts and sources in their logical and chronological sequence. 
The use of this methodology made it possible to carry out a systematic, specific-historical analysis of the progression of scientific thought in conjunction with objective-historical conditions and subjective-personal factors and to implement an important research task consisting in the study of the process of historical knowledge accumulation through obtaining reliable scientific results. On the basis of objective scientific analysis of a wide range of diverse sources and research literature, including historical, legal and statistical studies, in the field of theoretical developments on the problem under study, we used modern scientific methodological approaches that fully integrate the specifics of the process under research as a socio-cultural phenomenon and the features of its evolution in the practice of volunteer projects. Statistical data obtained from official sources and from studies conducted by other authors (secondary analysis of data) were analyzed and processed using statistical methods as well as result visualization methods.

\section{Findings and Discussion}

Onset of a new stage in the development of Russian volunteer movement in the field of preservation of cultural monuments coincided with the rise of research interest in volunteering in general.

Volunteering as a social phenomenon originated in the United States, where in the $19^{\text {th }}$ century volunteers supported the functioning of various non-profit organizations (Ascoli \& Cnaan, 1997). In 1920, the values of solidarity and mutual assistance were revived in Europe. That summer, a group of volunteers from Austria, England, Germany and Sweden gathered together to rebuild the village near Verdun (France), which was destroyed in the battle of World War I that claimed more than a million lives (Stjernø, 2009; Beito, 2003; Donnelly, 2006). From this first international volunteer camp in the history of mankind the first volunteer movement emerged, which still exists today (Harder, 1980).

Today, there are different volunteer projects, which differ by areas of activity and by the goals and tasks they are intended to solve. Such projects include environmental projects (Bruyere \& Rappe, 2007; Halpenny \& Caissie, 2003), humanitarian projects (Nordlund, 2009; Beigbeder, 1991), cultural and historical projects aimed at preserving historical monuments (Lin, 2010; MurzynKupisz \& Działek, 2013).

It is this direction that allows attracting people of different ages, social status and level of education to the ranks of volunteers. Volunteer work is perceived as an opportunity to participate in public life. In this regard, volunteering means taking personal responsibility for others and for the community as a whole.

The first volunteer restoration camps appeared in the 1960s. Today, architectural and restoration camps as social projects are especially popular in Europe and most often organized in such countries as Germany, France, Switzerland, the Czech Republic and others (Spiridon et al., 2014; Hull \& Gobster, 2000).

The work in volunteer restoration camps is mainly connected with certain assistance to the local community, e.g. reconstruction of historical monuments, repair of roads, organization and holding of celebrations and national festivals on the territory of the cultural and historical site. When participating in the restoration project of the camp, the volunteers not only work, but also relax, get to know the country and local sights, study the cultural and social peculiarities of the region. Host organizations also arrange various cultural and recreational activities, tours around the region (Awad et al., 2013; von Essen et al., 2015).

Currently, organizations from 50 countries around the world, united by the UNESCO Coordinating Council, hold more than five hundred international youth work camps each year. All of them operate under the same principle: the project should be socially meaningful and bring value to people (Mazzetto, 2018; Hamed, 2017; Tocqueville, 1993).

The analysis of international experience and voluntary national practices allowed elaborating modern approaches to the development of the Russian cultural volunteering sector. At the moment, this sector of cultural volunteering in Russia is represented by major volunteer initiatives in the field of cultural heritage preservation. It should be noted that in 2018, in the light of the Year of the Volunteer, an attempt was made to create a new social movement "Volunteers-Restorers". Let's 
talk more specifically about analysis of the main subjects of modern restoration volunteering in Russia.

The most large-scale and systematic organizer of volunteer activities in the field of protection and restoration of cultural heritage sites in Russia is the All-Russian Society for the Protection of Historical and Cultural Monuments (VOOPIC), which is perfectly natural, taking into account the wealth of experience gained in the past millennium in using volunteers for conservation and restoration works (Kulemzin, 2015).

After a considerable break in the 1990s, the VOOPIC resumed mass work with volunteers in 2016. The departure point, from which the contemporary history of its volunteer movement began, was the Russian-French Forum "Volunteering for the Preservation of Cultural Heritage" organized by the Society, which took place on October 25, 2016 in Moscow. The Forum brought together representatives of 15 different national volunteer projects in the field of cultural heritage. At the forum, VOOPIC and REMPART signed a cooperation agreement, in which they agreed to exchange best practices in the preservation of cultural heritage, to cooperate on the organization of volunteer campuses, as well as to arrange an international exchange of volunteers.

Following the forum in Moscow in 2017, the All-Russian Society for the Protection of Historical and Cultural Monuments, jointly with REMPART, opened two volunteer campuses: at the Donskoy Monastery and the Palibin House, for which work a total of almost 500 people, including French volunteers, were involved (VOOPIC Campuses, 2018).

In the same year, VOOPIC concluded key agreements with the Ministry of Culture of the Russian Federation and the Federal Agency for State Property Management, which stipulated, among other things, the issues of involving volunteers and volunteer organizations for restoration projects.

Another important step in the development of restoration volunteering was receipt of a presidential grant for the educational project "Volunteering School." The project was implemented from January to April 2018 in cooperation with "Mosvolonter" Resource Volunteer Center, State Research Institute for Restoration and Moscow College of Architecture, Design and Reengineering $\mathrm{N}$ 26. Within the framework of the project, 300 volunteers learned about volunteer movement in general and cultural volunteering in particular, were introduced to foreign experience of restoration volunteering, took part in 3 practice workshops on cleaning wooden, stone and metal objects (The Renaissance: How volunteers help to preserve the historical heritage, 2018).

The measures taken to promote restoration volunteerism allowed VOOPIC to significantly expand its own volunteer practices in 2018: under its auspices, six international volunteer campuses were held in Russia during the Year of Volunteer, which worked for 9 sessions. The geography of the projects also changed: the Leningrad, Ryazan and Tver regions were added to the Moscow region.

The next major project in the field of restoration volunteerism, Tom Sawyer Fest (Tom Sawyer, 2019), is a dynamically developing project to restore houses in the historic part of the city. In 2016, Tom Sawyer Fest was recognized by UNESCO as a successful local community outreach initiative. In 2017, the festival was held in 11 cities of Russia, and in 2018 the project was already launched in 28 cities. During the project, 58 buildings were renovated by volunteers and 10 art objects were created.

The number of volunteers varies. For example, in Samara and Kazan more than 100 volunteers take part in the festival annually, in Ufa they are about 80 volunteers, and about 40 volunteers in Buzuluk.

The main difference of the festival from other projects involving volunteers in the conservation or restoration of cultural and architectural objects, is that "Tom Sawyer Fest" is implemented within a different legal field: at the festival volunteers work with the houses that do not belong to the cultural heritage and are not protected by the state, which radically changes and facilitates a procedure for obtaining permission for work.

One of the first in the contemporary history of restoration volunteering was the project "Common Cause. Revival of the Wooden Churches of the North" (2019) founded in 2006 by the priest Father Alexei Yakovlev. He was inspired by the example of Alexander Porfirievich Slepnin, a resident of the village of Vorzogory in the Arkhangelsk region, who, at his advanced age, with the 
help of his wife, without any special experience and education, began restoration of the local ancient St. Nicholas Church and was able to perform the first part of the accident prevention works, which allowed to save the unique church. Having heard from Father Alexei about a good deed, the parishioners of Moscow churches started providing financial assistance to the devotee. Further on the project was supported by church hierarchs and joined by the students, archaeologists, benefactors, and Orthodox activists began to join it.

Over the twelve-year history of the project, more than 270 expeditions took place in the Arkhangelsk and Vologda Regions, Karelia and Komi Republics, within the framework of which more than 350 wooden churches and chapels were examined, and in 137 of them the accident prevention and conservation works were performed. Every year, as a part of the Common Cause project (2019), accident prevention works in churches are also carried out by the Interregional Public Charity Organization Rural Church Centre.

The uniqueness of the "Rural Church" is that it was founded in 1988 and since then its voluntary history has not been interrupted, so this organization, along with the volunteer movement VOOPIC, is one of the most long-term projects in the field of restoration volunteering.

Organization started its activity with the rescue of the Transfiguration Church in the village of Chentsy in the Kashinsky District of Tver Region. Since then, the "Rural Church" has brought back to life more than 50 churches in the villages of Central Russia.

Moscow public movement "Arkhnadzor" stands out among the volunteering projects in the field of protection and restoration of cultural heritage. "Arkhnadzor" does not perform restoration and conservation works, but is active in identifying, photographing and studying the monuments of the Moscow antiquity, assisting in their placement under the state protection, it conducts public monitoring of the condition and use of historical monuments and architecture in Moscow, fights against violations of legislation concerning protection of cultural heritage sites, develops proposals for the preservation of historical monuments, sights and landscapes, and organizes independent legal, artistic, technical and other expertise on the problems related to the cultural heritage of Moscow.

The movement was established in 2009 by representatives of public organizations and projects operating in the field of cultural and historical monuments protection. During the 9 years of its existence, "Arkhnadzor" has organized more than 100 events and projects: pickets, demonstrations, exhibitions, flash mobs, excursions and other events.

In 2015, Arkhnadzor jointly with the Moscow Architectural Institute (MARHI) launched the Heritage School, which mission is to attract the widest possible social audience to the preservation of tangible and intangible cultural heritage. The classes at the Heritage School are conducted by leading Russian theorists and practitioners and are attended by more than 2,000 people per semester, which indicates the high demand for the project.

Mono-object volunteer projects in the field of cultural heritage preservation are widely implemented in modern Russia. Let's focus on the most famous ones.

The project "Zapovednoe Darovoe - Dostoevsky's Estate", initiated by Vladimir Aleksandrovich Viktorovich, Doctor of Philological Sciences, Professor at Kolomna Pedagogical Institute (now State Social and Humanitarian University), started in 2003 with student expeditions to the village of Darovoye, which before the revolution belonged to the Dostoevsky family and where the great writer spent his childhood. In 2011, the Non-Commercial Partnership for the Revival of Natural Monuments and Cultural Monuments "Cultural-Educational, Scientific-Restoration and Museum Center "Zapovednoe Darovoe" was established, which allowed to bring the project to a new, higher level and gave the opportunity to participate in grant contests.

The specific feature of this project is that it is one of the few that uses a tool in its volunteer program, such as student internship, which was widely used in restoration volunteerism in the Soviet years. In the volunteer camp "Zapovednoe Darovoe" students of Moscow Institute for Humanities undertake their internships in folklore, dialectological and museum studies.

The next volunteer project we would like to highlight is the House with a Lion. In 2009, a unique wooden peasant house with painted interior of the late $19^{\text {th }}$ and early $20^{\text {th }}$ centuries was discovered by the students' folklore expedition in the village Popovka of Khvalynsky district of Saratov region. The house was abandoned, and its owners wanted to sell it for demolition. The 
interns who discovered the house told the world about it and thus changed its fate.

In 2010, Yulia Terekhova, a student of art history from St. Petersburg, saw a photo of this house at the conference of photography art historians. The house was at a risk of loss, and Julia and her friends purchased it in 2011 for 80 thousand rubles.

The house was in critical condition, the roof was leaking, the attic was littered with bricks, and the yard was heavily cluttered with garbage, the porch collapsed. A team of volunteers was built via the Internet, who settled in the village school and cleaned the house and the area around for several months.

Terekhova and her co-thinkers registered an autonomous non-profit organization and in 2012 won a grant from the Potanin Foundation "Changing Museum in a Changing World". In 2013, with the grant, the Monumental Folk Painting Museum was opened in the house, the museum's website with a virtual tour was created, and an audio guide for the museum was created. In 2014, the project received another grant, this time from the Timchenko Foundation "Cultural Mosaic of Small Towns and Villages", on which a cultural center was built near the house with a lion.

In total, 15 volunteer restoration camps have been held within the framework of the House with a Lion project to date, with more than 300 volunteers taking part in them.

Another well-known project built around a specific site is the project to preserve and revive the Church of the Nativity of Christ in the former village of Krokhino. During the expedition to Belozero, the project initiator Anor Tukaeva got acquainted with the Church of the Nativity, which was partially flooded during the construction of the Sheksna water reservoir. Wishing to save the church dating back to the 18th century, which remained the only evidence of the existence of the village of Krokhino, Anor in 2010 established the Charitable Foundation "Center for Revival of Cultural Heritage "Krokhino" (Lighthouses of the Soul, 2015).

From 2011 to 2015 the head organized more than 25 volunteer expeditions to Krokhino to carry out accident-prevention works in the Church of the Nativity of Christ. During the five seasons of work, more than 200 volunteers visited Krokhino, 12 tonnes of cement and 33 tonnes of sand were transported to the church island, and 1,250 bags of brick crumbs were laid into the man-made dam, fortified with $180 \mathrm{~m}$ of the steel-wire mesh (Lighthouses of the Soul, 2015)

However, as revealed by the analysis, there are a number of factors that influence the pace of development of restoration volunteering in modern Russia, and there are the measures that could be taken to support it.

The most obvious and urgent measures to support the volunteering movement for the preservation of historical and cultural monuments are legal and regulatory measures, among which the most crucial one is to overcome existing legal barriers.

The main barrier for volunteering in the field of preservation and restoration of cultural heritage sites is the provisions of the Federal Law of 25.06.2002 N 73-FZ "On Cultural Heritage Sites (Historical and Cultural Monuments) of the Peoples of the Russian Federation", according to which it is practically impossible for volunteers to carry out restoration and conservation work on cultural heritage sites on a legal basis. However, this bill, although legitimizing the participation of volunteers in the restoration and conservation of cultural monuments, will not change the legal situation with the involvement of volunteering professionals with the necessary knowledge and skills in the qualified restoration works.

The next package of actions, the implementation of which may significantly affect the development of restoration volunteering in Russia, are infrastructural and organizational measures.

It is obvious that the regulation of such a specific branch of voluntary movement as volunteering in the field of cultural heritage preservation requires establishment of a special entity with appropriate powers, authority and qualifications.

VOOPIC with the support of the Association of Volunteer Centers of Russia made a proposal to create a Resource Center for Supporting Volunteer Movements in the Field of Cultural Heritage Preservation. This center will be able to accumulate and disseminate the best methods and technologies of restoration volunteering, provide information, methodological, organizational and legal assistance to the organizers of volunteer projects in the field of heritage, and possibly become a tool for financing individual initiatives.

In addition to the above mentioned support activities, awareness raising measures are highly 
important for the development of volunteer initiatives.

In order to promote restoration volunteering, it is necessary to form a media group at the Resource Center for Supporting Volunteer Movements in the Field of Cultural Heritage Preservation to enrich the resources with vivid profile content and to moderate the materials submitted by the organizers of volunteer projects.

\section{Conclusion}

The very concept of the volunteer movement originated in Russia a long time ago, but is now experiencing the peak of its development. Volunteer movement in our country is becoming more and more popular every year. One of the areas in which volunteer work is so vital is the preservation of our country's amazing cultural heritage. Thanks to this area, every person who is not indifferent can literally touch the history of our country and help preserve the memory and culture of Russia, and not only. Unfortunately, in the field of restoration volunteering, our country is just beginning to take serious steps.

The range of tasks and activities of the volunteer movement in preserving Russia's cultural heritage is much wider than that of the restorers themselves, who fulfill state orders to preserve the historical appearance of the historical objects. Thus, a lot of attention is paid by volunteers to awareness raising activities among local residents, and showing by their personal example the caring attitude to the objects of cultural heritage. Securing the further life of a church or a chapel after restoration is directly related to sparking the interest of local residents in the monument and its original functions: church ordinances, worships, and creation of a community around it.

Thanks to the efforts of volunteers, thousands of architectural monuments across the country have already been restored. Thus, we are witnessing a vigorous development of modern restoration volunteering: more than 3000 volunteers participate in volunteer projects in the field of preservation and restoration of cultural values annually.

\section{References}

Ascoli, U., \& Cnaan, R.A. (1997). Volunteering for human service provisions: lessons from Italy and the USA. Social Indicators Research, 40(3), 299-327.

Awad, R., Chambers, J., \& Jupp, J. (2013). Volunteer tourism and architecture students: what motivates and can best prepare them. Journal of Pedagogic Development, 3(1), 6-12.

Beigbeder, Y. (1991). The Role and Statuts of International Humanitarian Volunteers and Organizations: The Right and Duty to Humanitarian Assistance. Dordrecht (The Netherlands): Martinus Nijhoff Publishers.

Beito, D.T. (2003). From mutual aid to the welfare state: Fraternal societies and social services, 1890-1967. Chapel Hill: The University of North Carolina Press.

Bruyere, B., \& Rappe, S. (2007). Identifying the motivations of environmental volunteers. Journal of Environmental Planning and Management, 50(4), 503-516.

Donnelly, J. (2006). Sovereign inequalities and hierarchy in anarchy: American power and international society. European Journal of International Relations, 12(2), 139-170.

Efremov, A.A., Sokolov, O.M., \& Barpholomeev, Yu.A. (2003). Organization of the first all-Russian student construction unit in Arkhangelsk region. News of the Higher Education Institutions. Forest Magazine, 3, 136-140.

Ermolenko, L.P. (2014). A public initiative to preserve cultural heritage in the 1960s - 1980s. in the North Caucasus. News of Volgograd State Pedagogical University, 4, 110-113.

Essen, J. von, Hustinx, L., Haers, J., \& Mels, S. (2015). Religion and volunteering. In: Religion and Volunteering (pp. 1-20). Springer, Cham.

Gorlova, N.I. (2017a). About the history of the development of the restoration volunteer movement in the 1960s1980s. Bulleting of Ryazan State University named after S.A. Esenin, 4(57), 75-81.

Gorlova, N.I. (2017b). Volunteer and community associations preserving the Russia's cultural heritage - History and Modernity. Annals of Scientific Conferences, 6-3(22), 38-43.

Halpenny, E.A., \& Caissie, L.T. (2003). Volunteering on nature conservation projects: volunteer experience, attitudes and values. Tourism Recreation Research, 28(3), 25-33.

Hamed, H.M. (2017). Voluntourism for Preserving Heritage: An Initiative for Safeguarding and Developing New Gourna in Egypt. Journal of Tourism and Hospitality Management, 5(1), 34-45. 
Harder, B. (1980). The Student Volunteer Movement for Foreign Missions and Its Contribution to $20^{\text {th }}$ Century Missions. Missiology, 8(2), 141-154.

Hull, R.B., \& Gobster, P.H. (2000). Restoring forest ecosystems: The human dimension. Journal of Forestry, 98(8), 32-36.

Kulemzin, A.M. (2015). Innovations and traditions in the preservation of cultural heritage. Bulletin of Kemerovo State University, 2, 52-54.

Kulemzin, A.M. (2001). Protection of Russian monuments as a historical and cultural phenomenon. Kemerovo.

Lighthouses of the Soul (2015). Muscovite restores the last flooded church in Russia (All-Russian Newspaper "Arguments \& Facts" (Federal Issue), May 21, 2015). Retrieved from http://www.aif.ru/society/people/mayaki_dushi_moskvichka_vosstanavlivaet_posledniy_v_rossii_zatoplen nyy_hram on January 28, 2019.

Lin, J. (2010). The power of urban ethnic places: cultural heritage and community life. Routledge.

Livtsov, V.A. (2017). Relations of the All-Russian Society for the Protection of Historical and Cultural Monuments with the state authorities in 2012-2015. Herald of State and Municipal Administration, 2(25), 36-42.

Livtsov, V.A. (2015). Historical development stages of the All-Russian Society for the Protection of Historical and Cultural Monuments. Local History Notes, 12, 216-220.

Livtsov, V.A. (2011). Participation of the All-Russian Society for the Protection of Historical and Cultural Monuments (VOOPIC) in preservation of the cultural heritage of the peoples of the Russian Federation. In: Collected works: $75^{\text {th }}$ Anniversary of the Roerich Pact, Proceedings of the International Scientific Society Conference 2010. (pp. 317-336). Moscow: International Center of the Roerichs publishing house.

Mazzetto, S. (2018). Heritage Restoration as a Tool to Promote Architectural Identity in the Gulf Regions. Preservation, Digital Technology \& Culture, 47(1), 3-11.

Murzyn-Kupisz, M., \& Działek, J. (2013). Cultural heritage in building and enhancing social capital. Journal of Cultural Heritage Management and Sustainable Development, 3(1), 35-54.

Nordlund, J.J. (2009). Volunteering for humanitarian projects. Clinics in Dermatology, 27(4), 395-400.

Pereslegin, N.V. (2015). History of the formation and development of agencies for the protection of the architectural heritage of Moscow in the context of their interaction with society in the Soviet period (19171991): PhD thesis. Moscow.

Project "Common Cause. Revival of the Wooden Churches of the North (2019). Retrieved from https://obsheedelo.ru/ on January 28, 2019.

Spiridon, P., Kosic, M., \& Tuci, B. (2014). Cre-Active Youth Promoting Cultural Heritage for Tomorrow. Ad Alta: Journal of Interdisciplinary Research, 4(2), 39-41.

State report on the culture in the Russian Federation (2017). Retrieved from http://docs.cntd.ru/document/551247005 on January 28, 2019.

Stjernø, S. (2009). Solidarity in Europe: The history of an idea. Cambridge University Press.

The Renaissance: How volunteers help to preserve the historical heritage (2018). Retrieved from https://sn.ria.ru/20180917/1528570207.html on January 28, 2019.

Tocqueville, A. de (1993). Volunteers in the Historic House Museum. In: Sh. Butcher-Younghans (Ed.), Historic House Museums: A Practical Handbook for Their Care, Preservation, and Management (p. 225). New York: Oxford University Press.

Tom Sawyer Fest (2019). Retrieved from http://tsfest.ru/ on January 28, 2019.

VOOPIC Campuses (2018). Retrieved from http://volunteer.voopik.ru/ on January 28, 2019. 